Proc. Indian Acad. Sci. (Earth Planet. Sci.), Vol. 95, No. 2, July 1986, pp. 299-309.

(C) Printed in India.

\title{
Global features of sea-level pressure distribution in April and July associated with contrasting situations of Indian summer monsoon
}

\author{
K RUPA KUMAR and L S HINGANE \\ Indian Institute of Tropical Meteorology, Pune 411005 , India
}

MS received 9 December 1985; revised 7 April 1986

\begin{abstract}
Global sea-level pressure distribution has been analysed for the months of April and July for 5 years of contrasting situations of Indian summer monsoon, comprising of two drought years (1972 and 1974), a flood year (1975) and two normal monsoon years (1970 and 1973). Mean monthly sea-level pressure data at about 400 stations have been used in the study. Prominent features of pressure departures from long-term normals have also been noted. It is observed that the month of April shows more prominent contrasting features than July. In April, the high pressure centres over USSR and the North Pacific move considerably eastward during poor monsoon years, while a breakaway cell of Icelandic Low goes deep south. Both the high pressure areas over south Indian Ocean and Australia are stronger in good monsoon years. In July, the subtropical high pressure zone over the southern Indian Ocean is stronger and the Australian high is more eastward, in good monsoon years.
\end{abstract}

Keywords. Southwest monsoon; global sea-level pressure; drought; pressure departures.

\section{Introduction}

Indian economy is very closely linked to the performance of the southwest monsoon, which contributes about $78 \%$ of the total rainfall over the country, during the four months from June to September. Though there are large spatial variations in the monsoon rainfall, the total rainfall received by the country appears to be fairly consistent, at least in the statistical sense, with a mean of $85.3 \mathrm{~cm}$ and coefficient of variation of $9.5 \%$ (Mooley and Parthasarathy 1984). However, it needs no emphasis that even these apparently small year-to-year variations have a phenomenal effect on agricultural and human activities in the country, so much so that a departure beyond $\pm 12 \%$ of the normal is associated with widespread flood/drought conditions. The date of onset and the duration of the active monsoon also play an important role in rainfall variations.

It is well known that the Asian summer monsoon is produced primarily by the seasonal shifting of thermally-produced planetary belts of pressure and winds under continental influences. The migration of the equatorial trough leads to a pressure gradient from the equator toward the Indian subcontinent, which has considerable influence on the transport of moisture and clouding toward the country. Thus, it is obvious that any mechanism which affects the surface pressure pattern in the region has a direct bearing upon the Indian monsoon rainfall. In this context, it would be useful to examine the nature of global surface pressure distribution associated with anomalous rainfall conditions over India, to identify certain large-scale patterns that may be significantly contributing to the rainfall variations.

Some studies have been made to understand the relation between the mean monthly 
global and hemispheric surface pressure distribution and the Indian monsoon rainfall. These studies essentially reduce the spatial distribution of the surface pressure into several principal components and then attempt to establish a relation with the rainfall. Paolino and Shukla (1981), who used Northern Hemispheric (NH) sea-level pressure data for 53 years (1925-77) did not find any evidence of a statistically significant relation between the sea level pressure anywhere over the NH during any month or season of the year and the monsoon rainfall over India. However, Chang and Yasunari (1982), who used global surface pressure data of July for 106 years (1871-1976), reported that the 2 nd component explained $19 \%$ of the total variance, reflecting a pressure seesaw between the subtropical oceans and the Afro-Eurasian continents, which seemed to be largely responsible for the strength of the Asian monsoon. They also reported that the 3 rd component accounted for $14 \%$ of the total variance, representing a north-south (or east-west) shift of the main centres of action, and was closely connected with the monsoon circulation. Parthasarathy (1984), using the data during the 106-year period 1871-1976, found a significant relationship between AllIndia monsoon rainfall and the 2 nd and 3rd principal components of $\mathrm{NH}$ sea-level pressure field in July, but not in January or April. He also analysed the relationship between 4 sea-level pressure centres of action and the Indian rainfall during the 80 years 1899-1978, and concluded that the Pacific high pressure during the preceding March-April-May was positively correlated with the monsoon rainfall, and that the Aleutian low pressure during the previous December-January-February was negatively correlated. He further reported that the mean pressure departures in these pressure centres of action during drought or flood years were generally less than $1 \mathrm{mb}$.

In the present study, the mean monthly global sea-level pressure distribution has been analysed for April and July, and an attempt is made to present a synoptic view of the contrasting features associated with poor and heavy monsoon situations over India.

\section{Data and analysis}

The years 1972 and 1974 are known to have witnessed widespread drought conditions all over the country, ranking as the 4th and 13th most severe drought years in the last hundred years, while the year 1975 was a heavy monsoon year, ranking 9th among large-scale excess years in the same period (Mooley and Parthasarathy 1984). The years 1970 and 1973 were normal monsoon years, with slightly excess rainfall. Seasonal

Table 1. All-India summer monsoon rainfall (June to September) and its departure from normal (after Mooley and Parthasarathy 1984).

\begin{tabular}{ccc}
\hline Year & $\begin{array}{c}\text { All-India } \\
\text { summer monsoon } \\
\text { rainfall (mm) }\end{array}$ & $\begin{array}{c}\text { Departure } \\
\text { from normal } \\
(\%)\end{array}$ \\
\hline 1970 & 939 & $+10 \cdot 1$ \\
1972 & 653 & $-23 \cdot 4$ \\
1973 & 912 & $+6 \cdot 9$ \\
1974 & 747 & $-12 \cdot 5$ \\
1975 & 960 & $+12 \cdot 5$ \\
\hline
\end{tabular}


rainfall values and the percentage departures from normal for these five years are given in table 1 (after Mooley and Parthasarathy 1984). To examine the global pressure distribution features in these five typical years, the authors have collected mean monthly sea-level pressure data at about 400 stations well-spread over the world (figure 1), for April and July from the Monthly Climatic Data for the World (NOAA/WMO). The features during April hold some predictive value for the following monsoon season while July coincides with the active period of the monsoon, giving some insight into the circulation mechanism. Detailed global charts of pressure distribution have been prepared for these two months of all the 5 years mentioned above. South of $60^{\circ} \mathrm{S}$, isobars could not be drawn as the data availability is meagre in that area. The authors have also computed the pressure departures from the long-term normals given by WMO (1971) and demarcated areas of positive and negative pressure departures on all the charts, by shading the areas under negative pressure anomalies. These charts are then critically examined to identify consistent contrasting features associated with heavy/poor monsoon situations over India.

\section{Results}

The following are some of the salient features noticed on the global sea-level pressure charts.

\subsection{April}

In this month, significant contrast could not be seen in respect of the Arctic High and the Aleutian Low, except that the former was fairly strong (1028 mb) in the two years, 1975 (flood) and 1973 (normal). The seasonal low pressure area over the Indo-African

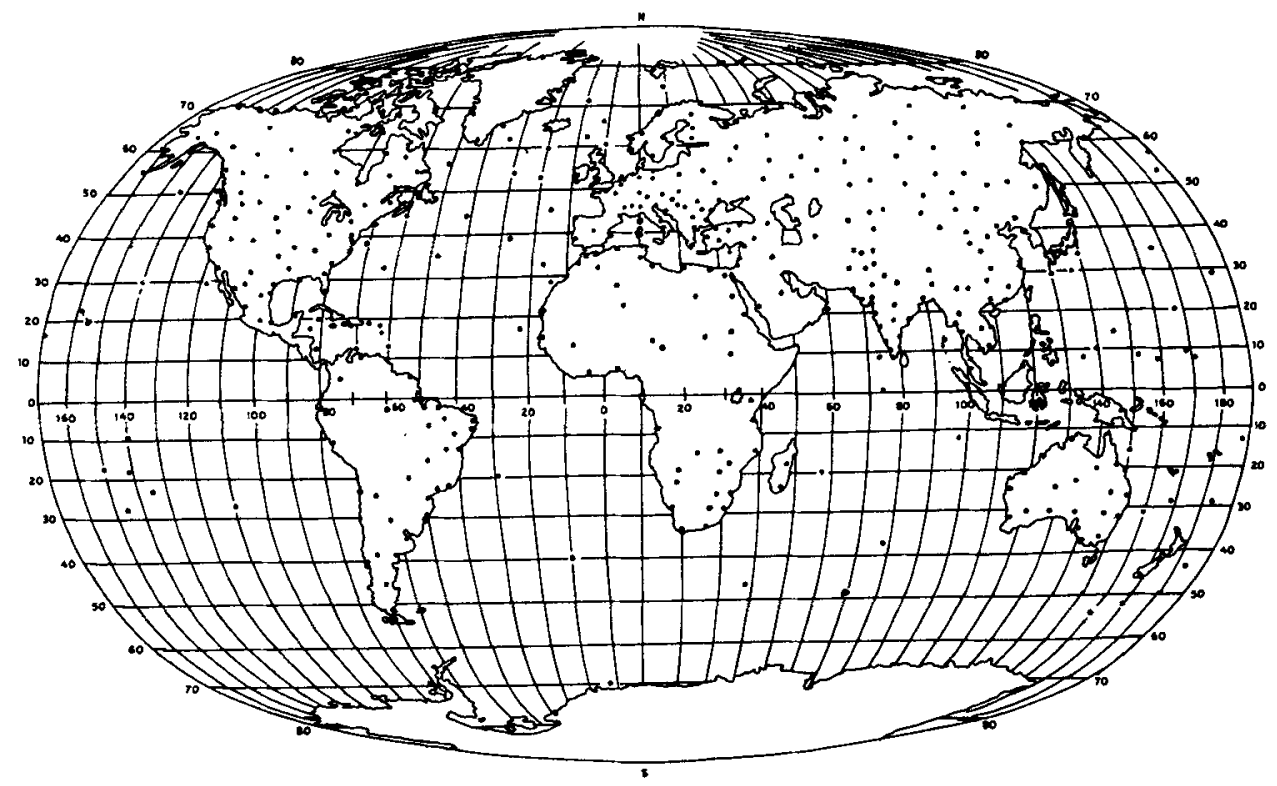

Figure 1. Locations of the stations for which data have been used. 
region also does not show marked differences between poor and good monsoon years. Other features that have shown some contrast are detailed below for each year.

(a) 1972: The Icelandic Low is well-established over North Atlantic (1007 mb), extending from the north-east Canadian Coast to Sweden (figure 2). Subtropical high pressure centres are over the eastern sides of north central Pacific (1021 mb) and north central Atlantic (1022 mb) oceans, and over North Korea and Japan (1023 mb) with east-west extensions into the Pacific High and central USSR. The Southern Hemisphere exhibits its characteristic smooth pressure pattern with high pressure areas off the south American Coast $(1023 \mathrm{mb})$ and over South Australia $(1021 \mathrm{mb})$, the latter having a slight zonal extension into the adjoining Indian Ocean.

It has been observed that pressure departures, negative as well as positive, are relatively weak all over the globe (within $\pm 2-3 \mathrm{mb}$ ). However, it can be seen that there are broad areas of negative departures over the western parts of North America and the adjoining Pacific, Europe and central USSR, north of Japan, Africa and South Indian Ocean and adjoining areas, and the eastern portions of South America.

(b) 1974: The Icelandic Low (1007 mb) extends southwestward along the northern portions of the North American Coast (figure 3). Another zonally extended subpolar low (1006 mb) is seen over the northern parts of USSR. Besides the subtropical high pressure areas over the North Pacific $(1026 \mathrm{mb})$ and the North Atlantic $(1020 \mathrm{mb})$, smaller high pressure cells are present over the British Isles (1024 mb) and central USSR $(1017 \mathrm{mb})$. The subtropical high pressure zones in the Southern Hemisphere are zonally extended over the South Pacific $(1020 \mathrm{mb})$ and the South Indian Ocean (1020 mb).

Very strong positive pressure departures are seen over the British Isles, south of New Zealand, Peru coast, far north-east of USSR and in the Indian Ocean south of Masquarine Island. Strong negative anomalies are seen over north central USSR, west

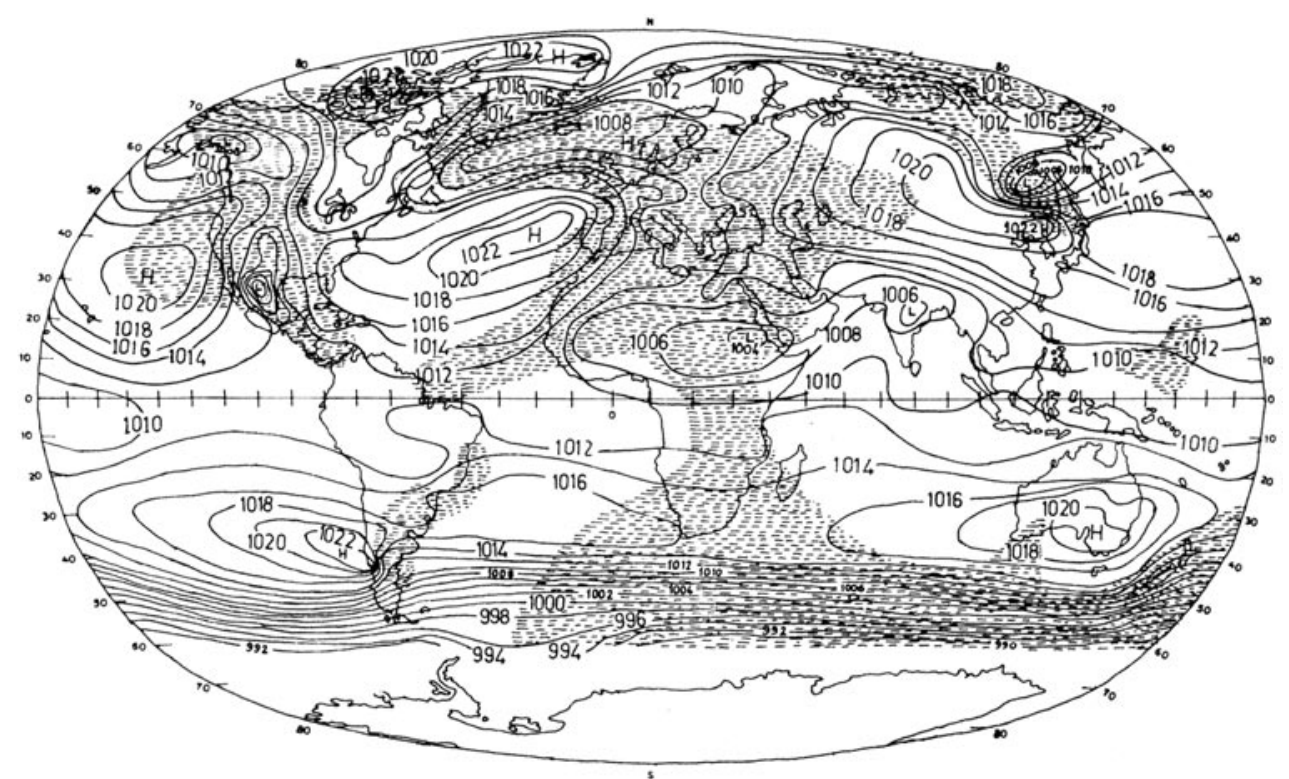

Figure 2. Mean sea-level pressure (mb) for April 1972. 


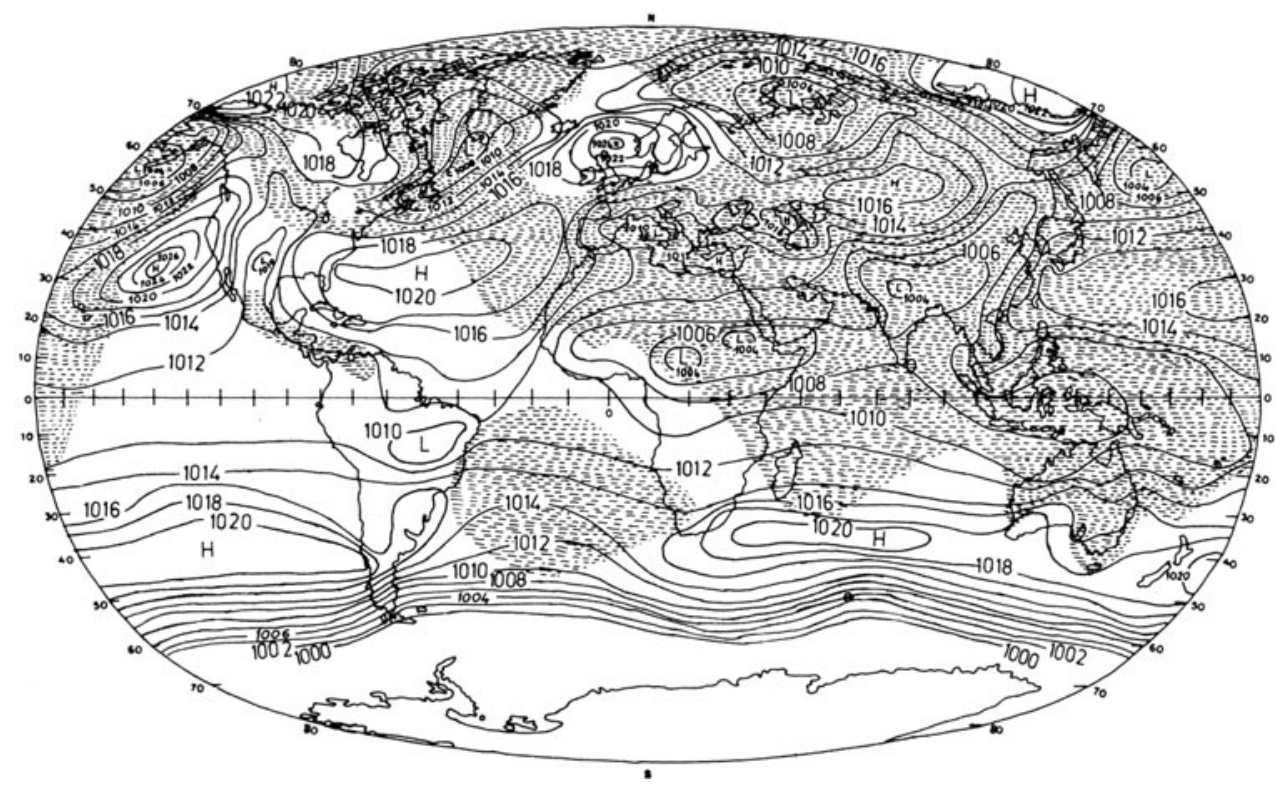

Figure 3. Mean sea-level pressure (mb) for April 1974.

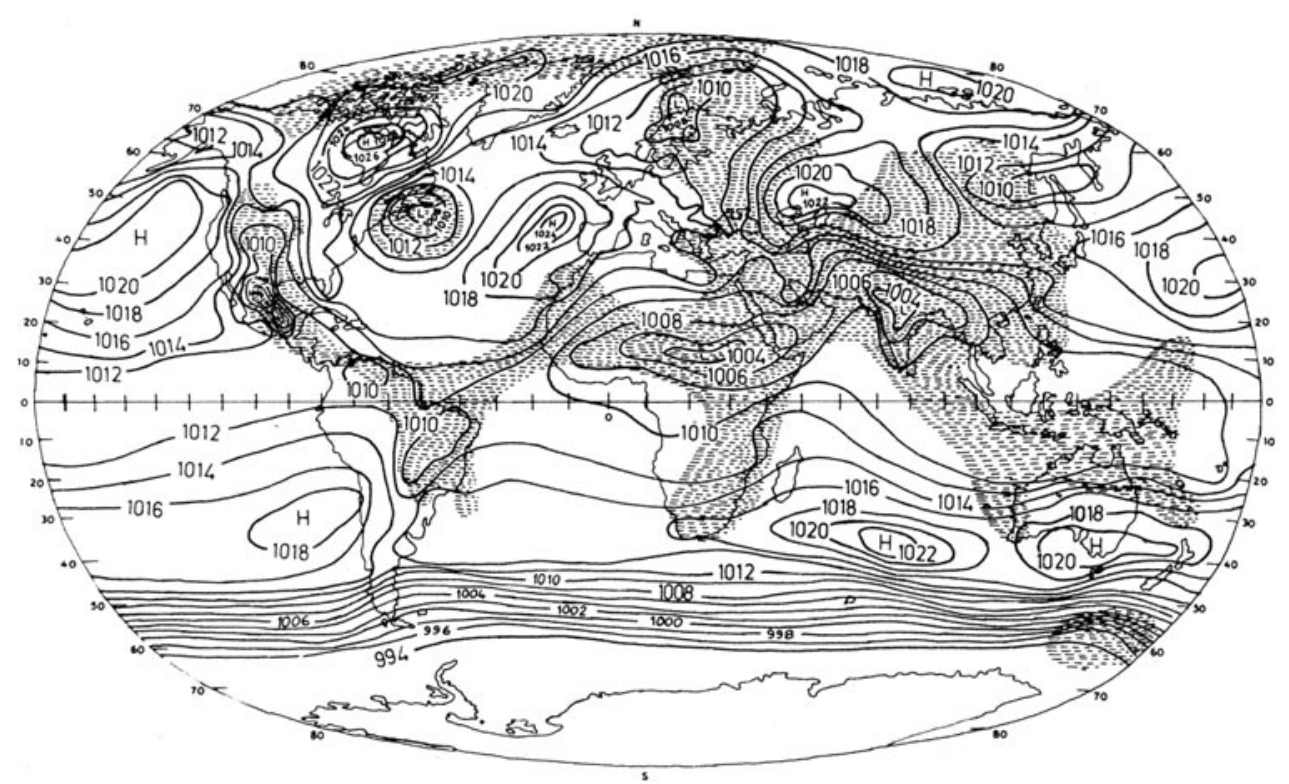

Figure 4. Mean sea-level pressure (mb) for April 1975.

of Greenland, Australia, west Pacific, north Africa and adjoining parts of Eurasia and equatorial Indian Ocean.

(c) 1975: The Icelandic Low is broken into two cells, one north of Sweden (1008 mb) over Finland and the other far to the south $\left(40^{\circ} \mathrm{N}\right)$ near the east coast of North America (figure 4). The subtropical high $(1020 \mathrm{mb})$ in the North Pacific is in the usual position. However, its counterparts are pushed eastward over the North Atlantic and 
westward over USSR. The subtropical high over the South Pacific is slightly towards north $\left(25^{\circ} \mathrm{S}\right)$. The high pressure area over south Indian Ocean extends zonally over almost the whole of the Eastern Hemisphere between $30^{\circ}$ and $40^{\circ} \mathrm{N}$, encompassing South Australia and New Zealand and is fairly strong (1020 and $1022 \mathrm{mb}$ ).

A very interesting feature shown by the pressure departures in this year is the positive anomalies over the ocean regions except in the Icelandic Low and a few other localized areas. Very strong positive anomalies occur over Northeast Canada $(+8 \mathrm{mb})$ and the southern tip of South America $(+13 \mathrm{mb})$. South Asia and its neighbouring continental areas are conspicuous by their negative pressure departures.

(d) 1970: The Icelandic Low is broken into two cells (figure 5), one over north central Atlantic (1008 mb) and the other over Sweden (1006 mb). Well-established subtropical high pressure areas are present over the North Pacific (1022 mb) and Central USSR (1024 mb). The high over the North Atlantic is pushed eastward (1024 mb). The subtropical high in South Pacific is fairly strong $(1020 \mathrm{mb})$. The South Indian Ocean and South Australia are covered by zonally extended high pressure cells (1018$1020 \mathrm{mb}$ ).

A relatively larger area over the globe is covered by positive pressure departures. This is particularly significant over the Southern Hemisphere where negative anomalies are confined to South Australia and the adjoining region. In the Northern Hemisphere, Canada, eastern USA and the adjoining North Atlantic, Central Africa and India, Europe and northern USSR show negative pressure departures.

(e) 1973: Icelandic Low comprises of two cells (figure 6), over North Central Atlantic $(1002 \mathrm{mb})$ and Sweden (1006 mb). The subtropical high in the North Pacific is welldefined (1022 mb) while that over the North Atlantic occurs as two separate cells, one considerably to the north near the UK $(1026 \mathrm{mb})$ and the other near the southeast coast of USA $(1017 \mathrm{mb})$. The subtropical continental high over central USSR is also fairly

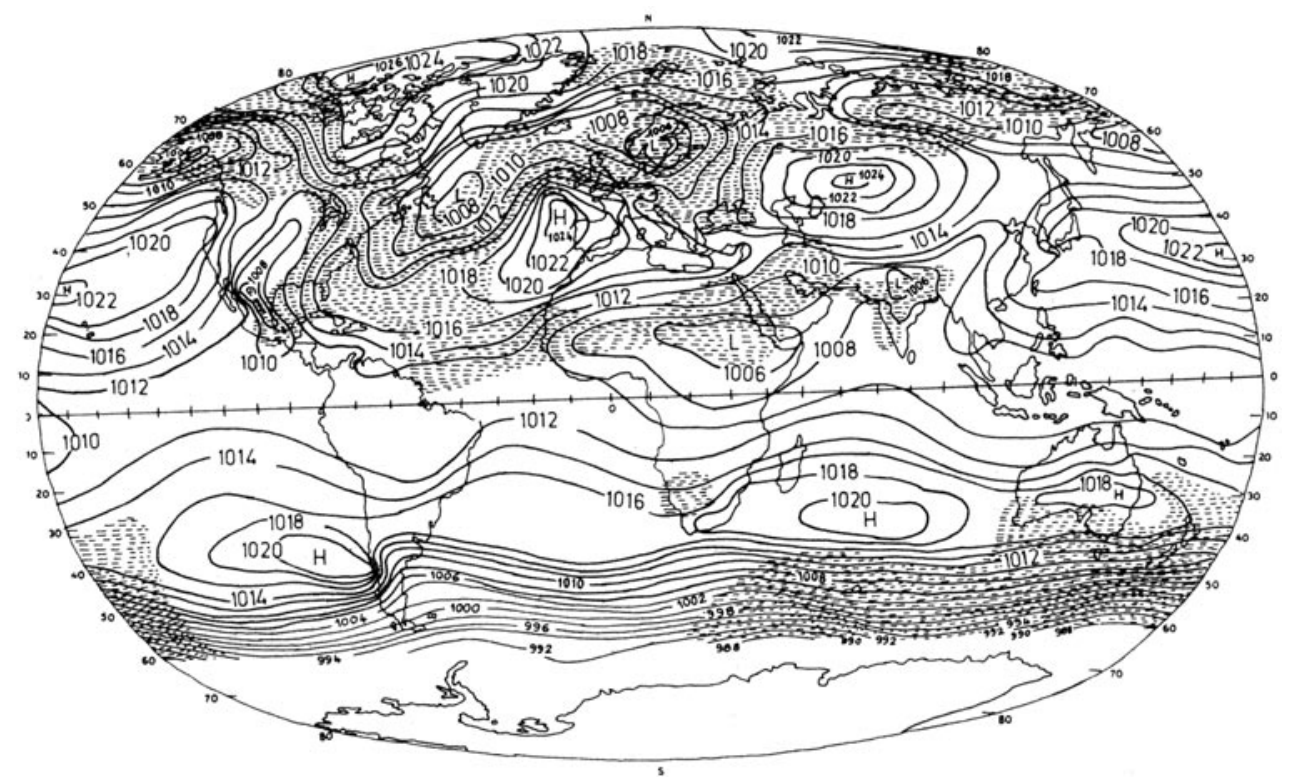

Figure 5. Mean sea-level pressure (mb) for April 1970. 


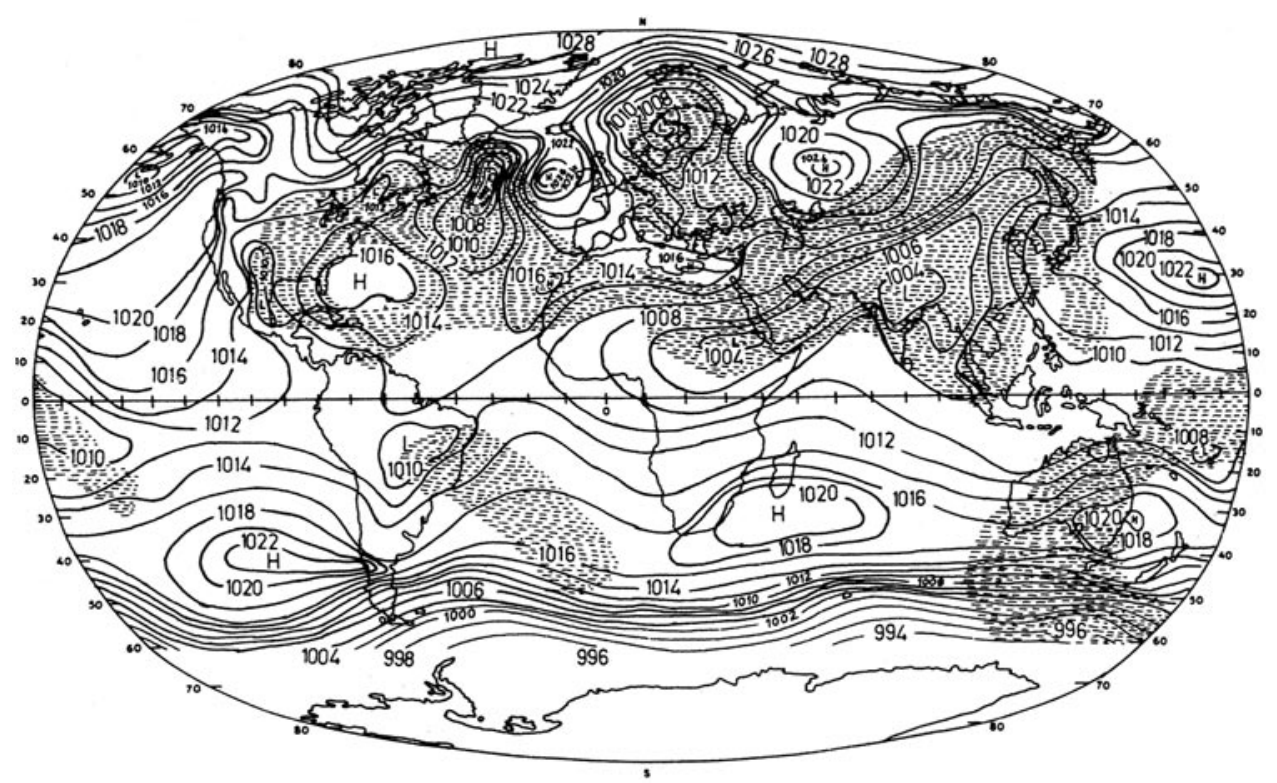

Figure 6. Mean sea-level pressure (mb) for April 1973.

strong (1024 mb). In the Southern Hemisphere, the sub-tropical high pressure zones over South Pacific, South Indian Ocean and Southwest Australia are prominent (1020-1022 mb).

A larger area in the Southern Hemisphere is covered by positive pressure departures. In the Northern Hemisphere, the polar region and the North Pacific are the only major areas covered by positive anomalies. Prominent negative anomalies are seen over the areas under the Icelandic Low while strong positive anomalies are mainly over the polar region.

\subsection{July}

In July, none of the pressure systems in the Northern Hemisphere, either seasonal or semi-permanent, show significant differences between anomalous monsoon years. The contrasting features observed in the Southern Hemisphere are described below.

(a) 1972: In the Southern Hemisphere, the subtropical high pressure zone is composed of three distinct cells (figure 7) over the South Pacific (1019 mb), the east coast of South Africa (1022 mb) and Australia (1022 mb).

The whole of the Southern Hemisphere is covered by negative pressure departures, except the eastern parts of the South Atlantic and the South Indian Ocean, and their adjoining continental areas of Africa and Australia. In the Northern Hemisphere, the North Pacific and the adjoining east Asia, the eastern portions of North Atlantic and the adjoining West Africa and the Icelandic Low show negative anomalies. Strong positive anomalies are seen over northern Europe and the Arctic High.

(b) 1974: The pressure features over the Southern Hemisphere in this year were similar to those in 1972, except that the South Pacific High was much stronger $(1030 \mathrm{mb})$ in 1974. Two other high pressure cells, onc zonally extended over the South Atlantic protruding into the South Indian Ocean (1023 mb) and the other relatively weak over Australia (1019 mb), are conspicuous. 


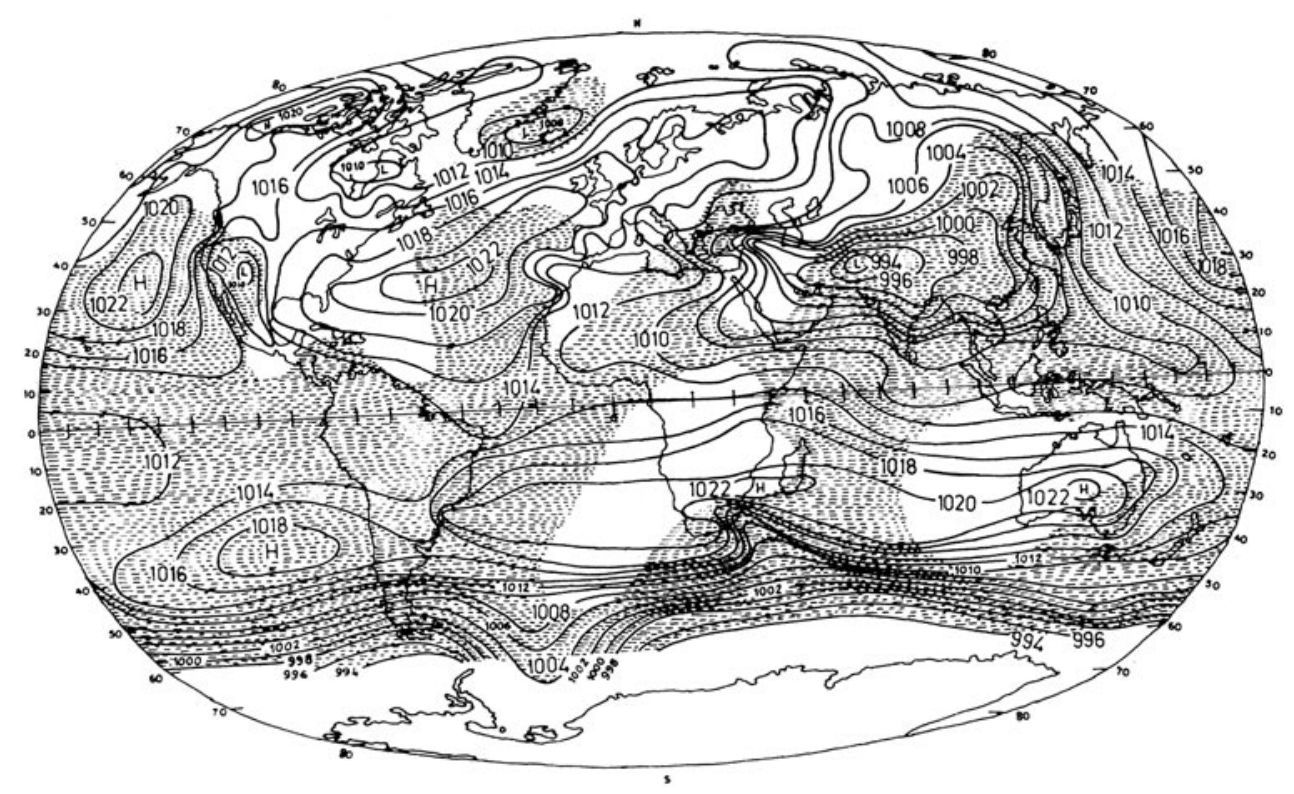

Figure 7. Mean sea-level pressure (mb) for July 1972.

A major part of the Eastern Hemisphere is covered by negative pressure departures. They are particularly high over the northern subpolar lows. The pressure anomalies suggest that the high pressure zones in the North and South Pacific as well as the Atlantic are stronger than normal.

(c) 1975: In the Southern Hemisphere, the subtropical high pressure zone is marked by four well-marked cells (figure 8), in the South Pacific, the South Atlantic, the South Indian Ocean and Australia (1020-1022 mb).

The whole of Africa, Indian Ocean, equatorial Atlantic, and Australia are covered by negative pressure departures. A major part of North America and Greenland are also covered by high negative anomalies. Most of the Pacific Ocean, South America, northern Europe and USSR show positive departures. It may also be noted that the Indian region shows positive departures at all stations.

(d) 1970: The subtropical high in the Southern Hemisphere is composed of four distinct cells, as in 1975. Those over Australia and the South Pacific are relatively strong (1024 mb).

The subpolar regions in both the hemispheres have shown negative pressure departures. Major parts of the Pacific and Atlantic oceans are marked by positive anomalies. The eastern parts of India and the adjoining areas, as well as Australia show positive anomalies. The western and central parts of the Indian Ocean and the adjoining Africa show negative anomalies.

(e) 1973: In the Southern Hemisphere, the South Pacific High considerably moved southwestward and merged with the Australian High, forming a strong high pressure cell (1026 mb) southeast of Australia (figure 9). The high pressure cell over the South Indian ocean is well defined $(1022 \mathrm{mb})$.

The major part of the Northern Hemisphere is covered by negative pressure departures. Positive anomalies are predominantly seen over parts of Canada, central 


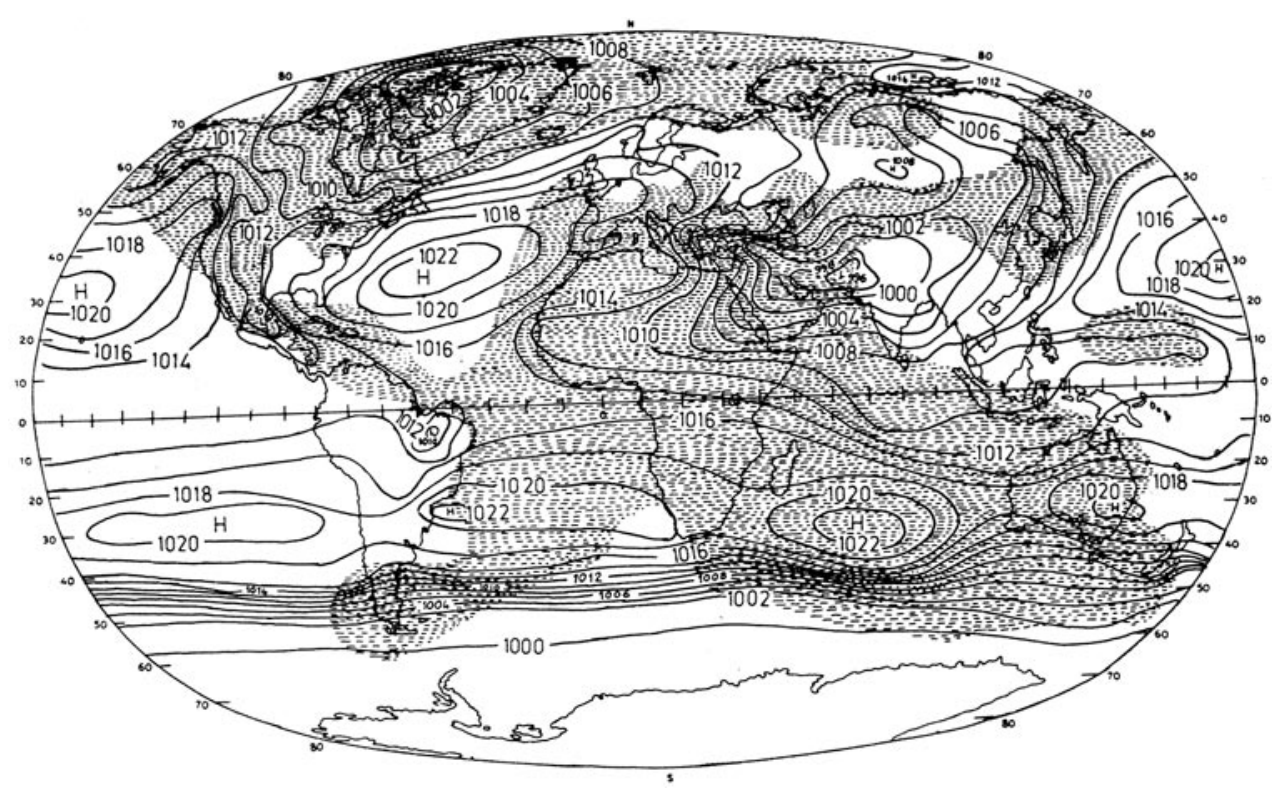

Figure 8. Mean sea-level pressure (mb) for July 1975.

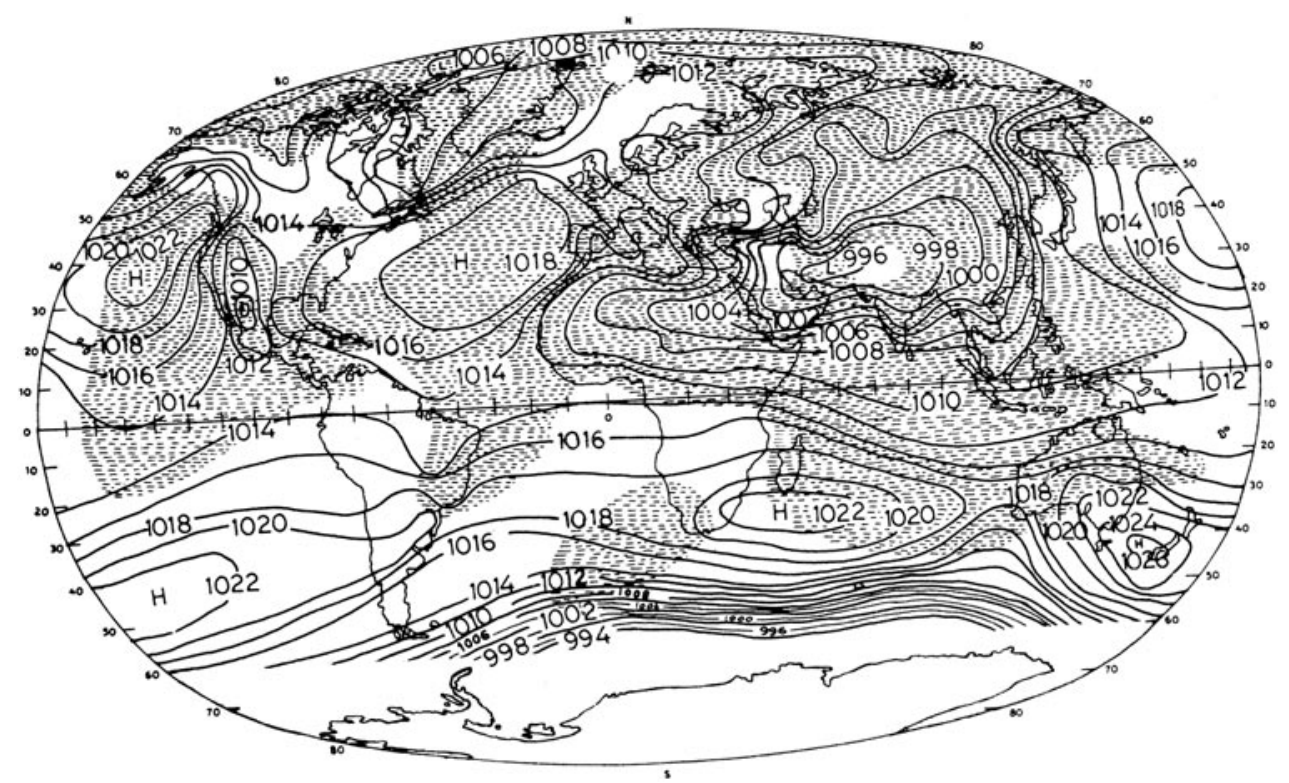

Figure 9. Mean sea-level pressure (mb) for July 1973.

parts of the North Pacific and the north of the British Isles. In the Southern Hemisphere, the Indian Ocean, Australia and the northeastern parts of Brazil show negative anomalies. Significantly high positive anomalies are seen over New Zealand and adjoining areas. 


\section{Discussion}

From the nature of the pressure distribution described above, some specific features of contrast can be pointed out as follows.

During April, the continental high over USSR as well as the North Pacific High are found to have shifted considerably eastward during poor monsoon years. Particularly in the drought year 1972, the USSR High reaches as far east as Korea (figure 2). During heavy and good monsoon years, these highs are considerably west of their usual positions. The Icelandic Low is poleward during April and covers contiguous areas in poor monsoon years whereas in good monsoon years it prominently breaks into two cells, one going deep south and the other remaining near the subpolar regions. The one coming south pushes part of the North Atlantic high pressure centre considerably northeastward over to the British Isles. In this month, the subtropical highs in the Southern Hemisphere over the South Indian Ocean and South Australia are both strong and well-established in good monsoon years while in drought years they are localized to only one region.

Regarding the prominent features of the pressure departures in April, the area covered by positive anomalies over a major part of the oceans is markedly larger in heavy monsoon years. Over the South Indian Ocean, the pressure departures are consistently positive in heavy and good monsoon years and negative in poor monsoon years. In the North Atlantic near Greenland, the departures are significantly negative in poor monsoon years and positive in good monsoon years. It is worth noting here that the overall pressure anomalies during the well-known drought year 1972 are weak all over the globe in April.

In July, the subtropical high pressure cell over the South Indian Ocean is not welldefined in drought years whereas it is quite marked and covers a larger area east of South Africa and Malagasy in good monsoon years. The Australian High is also further eastward during good monsoon years. Consistent differences in the pressure anomaly pattern for poor and good monsoon situations could not be noticed in July. However, it may be mentioned that the anomalies are positive over the Indian region particularly on the eastern part and over the Bay of Bengal during good monsoon years.

It is also to be noted here that no significant differences could be noticed regarding the seasonal lows over the Indo-African region in April and over Pakistan in July.

\section{Conclusions}

A comparative study of the global sea-level pressure distribution and pressure anomalies in April and July for poor and good monsoon situations over India, leads to the following conclusions. (i) The month of April shows more prominent contrasting features between poor and good monsoon years than July. (ii) In April, the high pressure centres over USSR and the North Pacific move considerably eastward during poor monsoon years. (iii) In April, a breakaway cell of the Icelandic Low comes deep south during good monsoon years. (iv) In April, the subtropical high pressure centres over the South Indian ocean and Australia are more well-established and stronger in good monsoon years. (v) Pressure departures over oceanic areas are predominantly positive in April for good monsoon years. (vi) In July, the subtropical high pressure cell 
over the South Indian ocean is more organised and stronger during good monsoon years. (vii) The Australian High is more eastward in July during good monsoon years. (viii) Significant differences in the pressure departures for July are not noticeable. (ix) Pressure departures are weak all over the globe in April of the well-known drought year 1972. (x) There are no significant differences in the characteristics of the seasonal lows over the Indo-African region and Pakistan for good and poor monsoon situations.

\section{Acknowledgements}

The authors are thankful to Dr G B Pant and Dr H N Bhalme for suggestions and encouragement.

\section{References}

Chang T and Yasunari T 1982 J. Meteorol. Soc. Jpn 601132.

Mooley D A and Parthasarathy B 1984 Climatic Change 6287.

Parthasarathy B 1984 Some aspects of large-scale fuctuations in the summer monsoon rainfall over India during 1871 to 1978 Ph.D. Thesis, University of Poona.

Paolino D and Shukla J 1981 Proc. of Symposium on tropical droughts, meteorological aspects and implications for agriculture, December 1981, New Delhi (Geneva: World Meteorological Organisation) p. 41.

WMO 1971 Climatological normals (CLINO) for CLIMAT and CLIMAT ship stations for the period 1931 60, WMO/OMM - No. 117, TP52, World Meteorological Organisation, Geneva, Switzerland. 